\title{
Cish actively silences tcr signaling in CD8+ $T$ cells to maintain tumor tolerance
}

\author{
Douglas Palmer ${ }^{1 *}$, Geoff Guittard² ${ }^{2}$ Zulmarie Franco², Shashank Patel ${ }^{2}$, Christopher A Klebanoff ${ }^{3}$, \\ Madhusudhanan Sukumar ${ }^{3}$, Robert L Eil ${ }^{1}$, David Clever $^{3}$, Lakshmi Balagopalan², Rahul Roychoudhuri ${ }^{3}$, \\ Larry Samelson², Nicholas Restifo
}

From 30th Annual Meeting and Associated Programs of the Society for Immunotherapy of Cancer (SITC 2015) National Harbor, MD, USA. 4-8 November 2015

\section{Background}

Improving the functional avidity of effector $\mathrm{T}$ cells is critical in overcoming inhibitory factors within the tumor microenvironment and eliciting tumor regression.

\section{Methods}

We have found that Cish, a member of the Suppressor of Cytokine Signaling (SOCS) family, is induced by TCR stimulation in $\mathrm{CD}^{+} \mathrm{T}$ cells and inhibits their functional avidity against tumor.

\section{Results}

Genetic deletion of Cish in $\mathrm{CD} 8^{+} \mathrm{T}$ cells enhances their expansion, functional avidity and cytokine polyfunctionality, resulting in pronounced and durable regression of established tumors. Although Cish is commonly thought to block STAT5 activation, we found that the primary molecular basis of Cish suppression is through inhibition of TCR signaling. Cish physically interacts with the TCR intermediate PLCg1, targeting it for proteasomal degradation following TCR stimulation. Furthermore we extend these findings to patients PBL retrovirally transduced with tumor-specific TCRs and shorthairpin microRNAs targeting $\mathrm{CISH}$.

\section{Conclusions}

These findings establish a novel targetable interaction that regulates the functional avidity of tumor-specific $\mathrm{CD}^{+} \mathrm{T}$ cells and can be manipulated to improve adoptive cancer immunotherapy.

${ }^{1} \mathrm{NIH} / \mathrm{NCl}$ - Surgery Branch, Bethesda, MD, USA

Full list of author information is available at the end of the article

\section{Authors' details}

${ }^{1} \mathrm{NIH} / \mathrm{NCl}$ - Surgery Branch, Bethesda, MD, USA. ${ }^{2} \mathrm{NCl}$, Bethesda, MD, USA.

${ }^{3}$ Center for Cancer Research, NCI/NIH, Bethesda, MD, USA.

Published: 4 November 2015
Submit your next manuscript to BioMed Central and take full advantage of:

- Convenient online submission

- Thorough peer review

- No space constraints or color figure charges

- Immediate publication on acceptance

- Inclusion in PubMed, CAS, Scopus and Google Scholar

- Research which is freely available for redistribution
() Biomed Central 